\title{
IMPORTOWANE NACZYNIE BRĄZOWE ZE STEMPLEM PUBLIUSZA CIPIUSZA POLIBIUSZA NA CMENTARZYSKU KURHANOWYM Z OKRESU WPLYWÓW RZYMSKICH W GRUDNEJ, POW. ZLOTOWSKI, STAN. 2
}

\author{
IMPORTED BRONZE SKILLET WITH A STAMP OF PUBLIUS \\ CIPIUS POLYBIUS FROM THE ROMAN IRON AGE BARROW \\ CEMETERY AT GRUDNA, SITE 2, ZŁOTÓW COUNTY
}

\author{
Igor Koloszuk \\ Instytut Prahistorii, Uniwersytet im. Adama Mickiewicza \\ ul. Umultowska 89D, 61-614 Poznań, Poland \\ igorkoloszuk@interia.pl
}

\begin{abstract}
During excavations at the Roman Iron Age barrow cemetery in Grudna there has been an imported skillet discovered with a stamp of Publius Cipius Polybius, a bronzesmith of Capua. It is one of several such vessels found in northern Barbaricum. The largest concentration of skillets has been observed on Danish islands, which at the time were a transit points on a northern trade route across the sea. The presence of the skillet in the area proves widespread, interregional contacts of people inhabiting the middle Gwda River basin in phase $\mathrm{B}_{2}$ of the Roman Iron Age.
\end{abstract}

KEY WORDS: barrow cemetery in Grudna, Publius Cipius Polibius, bronzesmither's stamp, P. CIPIPOLIBI.F.

\section{WSTĘP}

Przedmiotem opracowania jest brązowe naczynie odkryte podczas badań archeologicznych na stanowisku nr 2 w Grudnej, pow. złotowski, woj. wielkopolskie. Stanowi ono jeden z elementów wyposażenia grobowego, znalezionych podczas prac trwających tam w sierpniu 2012 r. oraz we wrześniu i październiku 2014 r., jednak ze względu na swą unikatowość wymaga osobnego opracowania.

Badania archeologiczne przeprowadzono na zlecenie Wielkopolskiego Konserwatora Zabytków w Poznaniu. Pracami, z ramienia Instytutu Prahistorii Uniwersytetu im. Adama Mickiewicza w Poznaniu, kierował mgr Igor Kołoszuk. W ramach 
badań wykonano pomiary geofizyczne oraz sporządzono plan warstwicowy stanowiska. W celu rozpoznania charakteru jednego z wybranych obiektów przebadano wykopaliskowo ćwiartkę „W” kurhanu nr 10.

\section{KONTEKST ODKRYCIA}

Pod zniwelowanym nasypem ziemnym zarejestrowano kamienną konstrukcję jądra kurhanu na warstwie spalenizny o miąższości ok. $25 \mathrm{~cm}$. Natomiast $1,5 \mathrm{~m}$ na zachód od niej znaleziono prostokątny obiekt o wymiarach $106 \times 390 \mathrm{~cm}$, który w trakcie dalszych prac zinterpretowano jako jamę grobową (ryc. 1). Jej eksploracja pozwoliła uchwycić wyraźne ślady intencjonalnej rozbiórki zwartej konstrukcji kamiennej, stanowiącej zapewne pierwotną obstawę i nakrycie grobu. W jego wnętrzu nie zarejestrowano szczątków ludzkich. Prawdopodobnie zostały one celowo usunięte. Oprócz śladów rozbiórki o ekshumacji szczątków świadczyć może także fakt pozostawienia w jamie elementów wyposażenia grobowego (ryc. 2). Wśród nich znajdowały się: szklany paciorek, gliniany przęślik, trzy żelazne gwoździe, brązowe i żelazne okucia od skrzynki wraz z nitami, fragment grzebienia kościanego, fragmenty szpili kościanej oraz fragmenty tkanin wełnianych, a także brązowe naczynie, które w typologii importów rzymskich wg H.J. Eggersa odpowiada typowi (Kasserolle) E 142 (Eggers 1951, s. 381, tab. 12).

Bezpośredni związek grobu z kurhanem nr 10 jest niejednoznaczny. Prawdopodobnie był to osobny obiekt pierwotnie ulokowany u podnóża nasypu (ryc. 1), który w wyniku procesów podepozycyjnych osunął się od strony zachodniej, pokrywając wystającą ponad poziom gruntu kamienną konstrukcję grobu ${ }^{1}$.

\section{NACZYNIE}

Zdeponowane w grobie naczynie miało formę rondla o długości $22,6 \mathrm{~cm}$, szerokości $12 \mathrm{~cm}$ i wysokości 7,3 cm (ryc. 3). Zachowało się w stanie bardzo dobrym. Niewielkie ubytki wystąpiły jedynie na części ścianki bocznej, którą wykonano z bardzo cienkiej blachy, natomiast dno i uchwyt naczynia odlano z grubszej warstwy

\footnotetext{
${ }^{1}$ Badania archeologiczne kontynuowane na stanowisku w Grudnej doprowadziły w 2014 r. do kompleksowego przebadania kurhanu nr 10. Pod kamiennym jądrem obiektu, w warstwę spalenizny wkopany był jamowy grób ciałopalny zawierający przepalone kości ludzkie wraz z licznymi przepalonymi fragmentami metalowych przedmiotów. Budowa kurhanu i forma pochówku (jamowy, ciałopalny) upodabniają go do obiektów zarejestrowanych w nieodległym Zelgniewie (Götze 1904, s. 3-5; Karpińska 1926, s. 22-23; Kokowski 1997b, s. 9-55). Badania przeprowadzone w 2014 r. nie ujawniły także w pobliżu kurhanu nr 10 obecności innych grobów poza opisywanym. Wzajemne relacje przestrzenne obu obiektów wymagają zatem bardziej szczegółowego rozpoznania. Stanie się ono jednym z przedmiotów osobnego opracowania.
} 


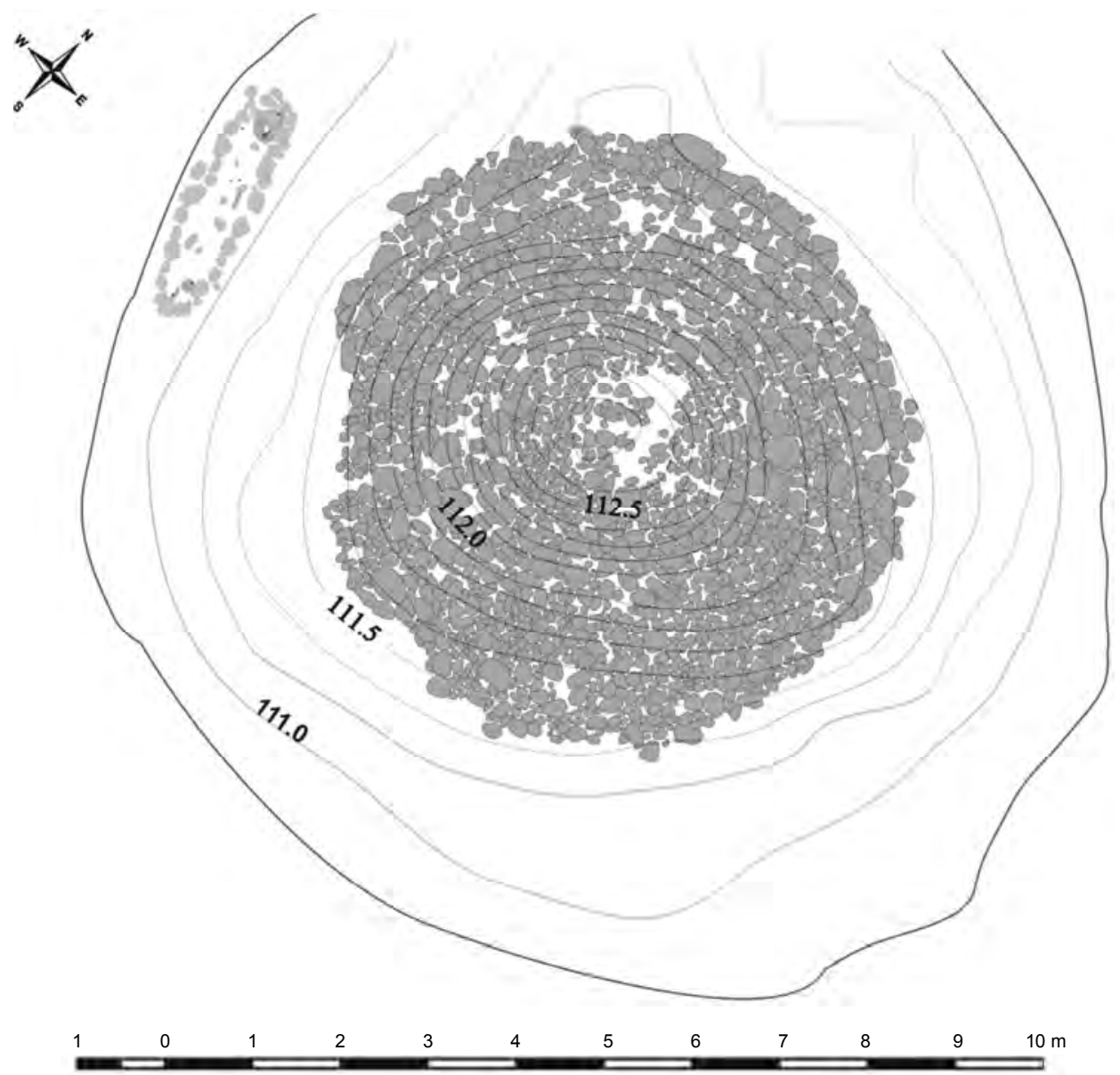

Ryc. 1. Grudna, stan. 2, pow. złotowski. Plan poziomu II kurhanu nr 10 z zaznaczoną lokalizacją grobu nr 1 i zasięgu nasypu kurhanowego

Fig. 1. Grudna, site 2, Złotów county. A layout of level II of barrow 10, with marked location of grave 1 and reach of a barrow bank

stopu. W dnie, od spodu wytoczono pięć centrycznie rozchodzących się kręgów (ryc. 3c). Sprawiło to, że stało się ono cieńsze i jednocześnie odporniejsze na przepalenia, a kręgi lepiej rozprowadzały ciepło. Takie ukształtowanie powierzchni dna spełniało istotną funkcję poprawiającą wydajność termiczną naczynia, które niewątpliwie miało służyć do szybkiego podgrzewania płynów (Bennet, Young 1981, s. 37). Ze względu na swą grubość to właśnie uchwyty i dna stanowią najlepiej zachowane, często jedyne odnajdywane części tego typu naczyń.

Płaska rączka naczynia znalezionego w jamie grobowej miała długość 10,6 cm, liczoną do znajdującej się na tej samej wysokości krawędzi wylewu. Następnie zwę- 


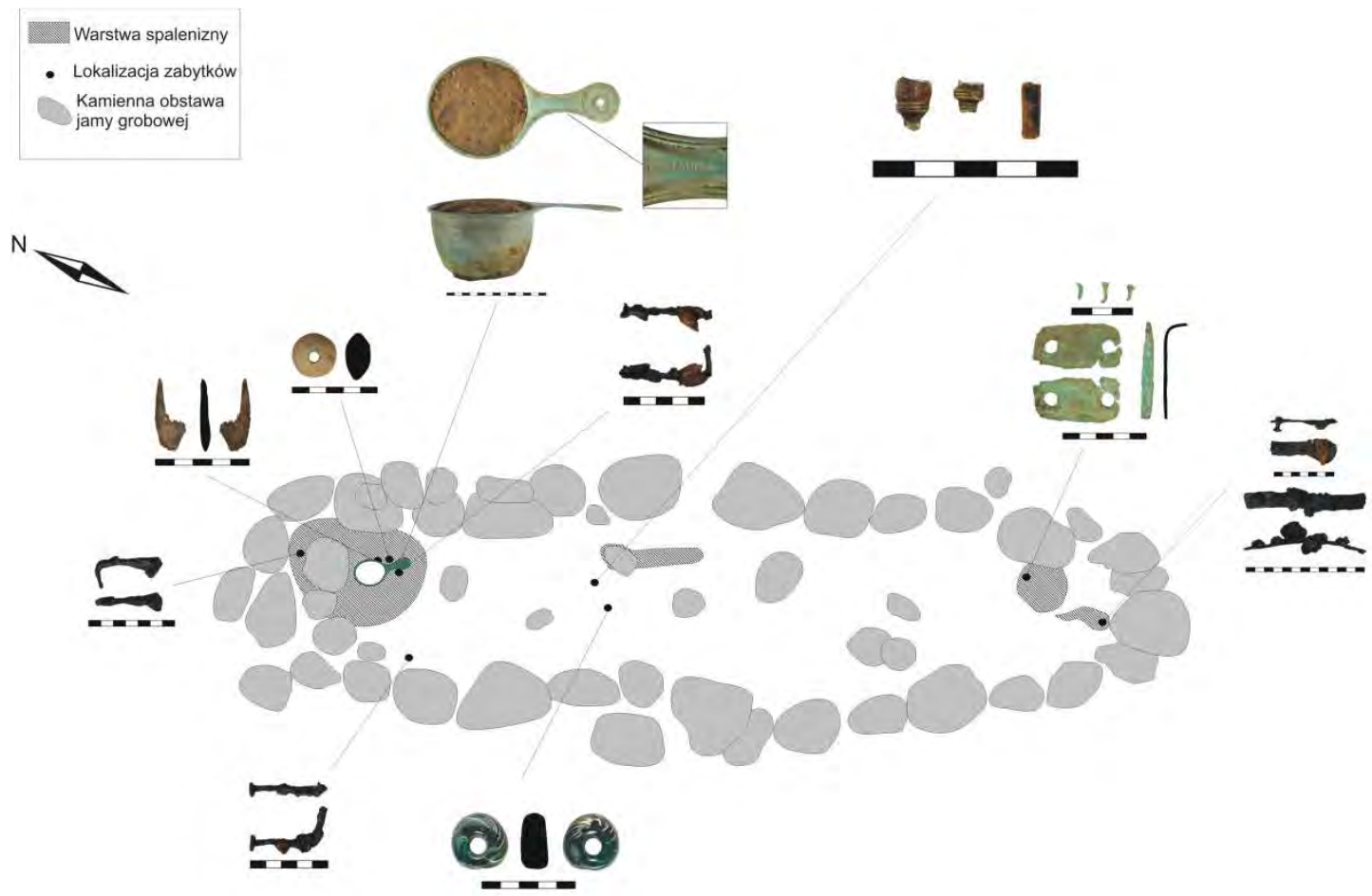

Ryc. 2. Grudna, stan. 2, pow. złotowski. Plan grobu nr 1 z zaznaczoną lokalizacją zabytków

Fig. 2. Grudna, site 2, Złotów county. A layout of grave 1 with marked location of artefacts

żała się symetrycznie po obu stronach, by mniej więcej w połowie swojej długości ponownie się rozszerzyć. Na jej poszerzonym i zaokrąglonym zakończeniu wytłoczono od góry dysk o średnicy $3,3 \mathrm{~cm}$ z centrycznie ulokowanym otworem o szerokości $0,6 \mathrm{~cm}$. Ponadto rączkę lekko wyprofilowano na obu brzegach, co utworzyło na środku od góry rodzaj grubszego „żeberka”. Jej krawędzie od wieńczącego ją dysku po krawędź wylewu były dodatkowo od góry zdobione ornamentem delikatnej postrzępionej linii, a na środku ,żeberka” odbito stempel wykonawcy (P.)CIPIPOLIBI (F) (ryc. 3a). Stempel ten wiązać należy z Publiuszem Cipiuszem Polibiuszem, rzymskim brązownikiem wytwarzającym naczynia w pobliżu Kapui mniej więcej w połowie I w. n.e. (Bennett, Young 1981, s. 37-44; Kunow 1985, s. 215-242; Willers, 1907).

Rondel znaleziony w Grudnej poddano jakościowej analizie LIBS wykonanej przez mgr. Pawła Kucyperę z Instytutu Archeologii UMK. Na powierzchni rondla wykonano serię pomiarów. Uzyskane dane pozwalają stwierdzić, że naczynie odlano z czystego stopu cynowo-cynkowego poddanego wcześniejszej rafinacji, o czym świad- 


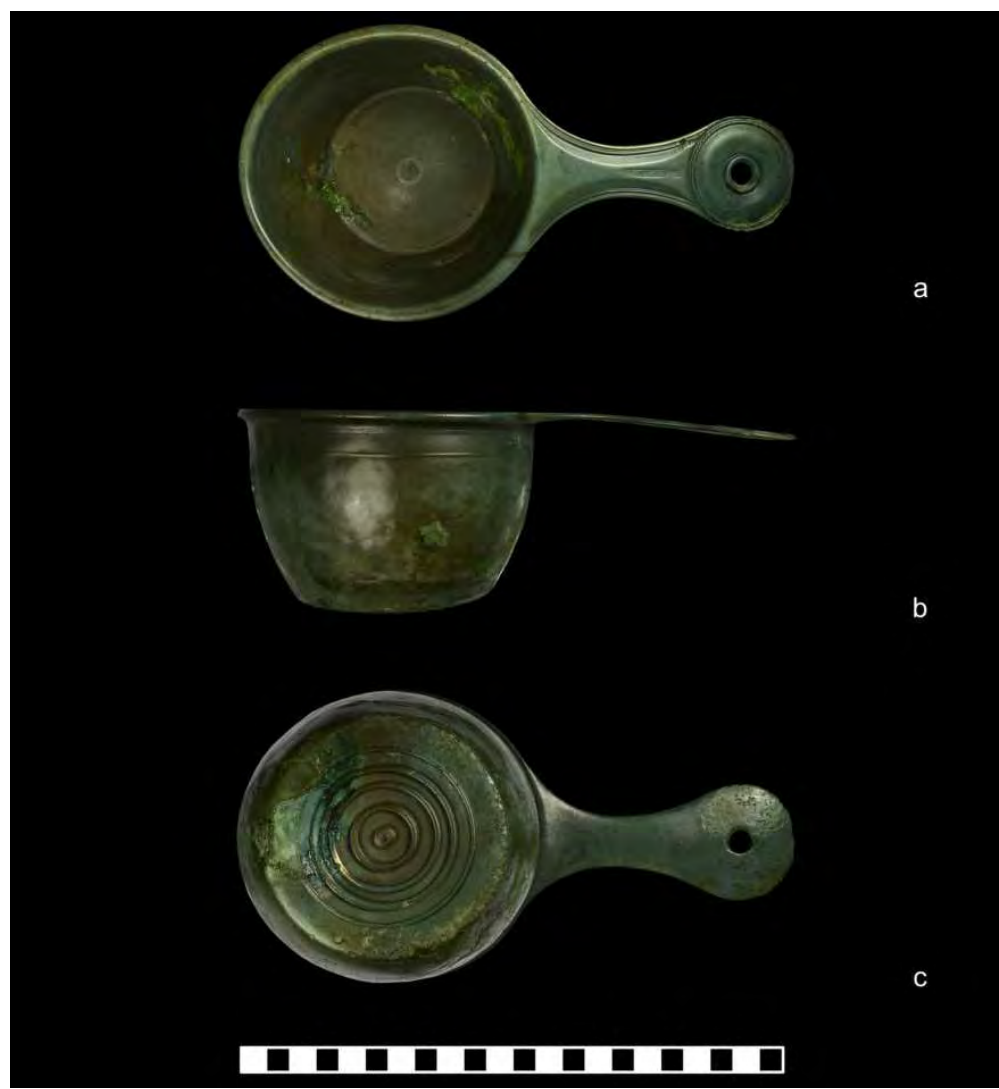

Ryc. 3. Grudna, stan. 2, pow. złotowski. Naczynie typu E142 znalezione w grobie nr 1 (fot. M. Gembicki) Fig. 3. Grudna, site 2, Złotów county. The skillet of E142 type from grave No. 1 (photo by M. Gembicki)

czą niskie koncentracje żelaza. Być może użyto powtórnie przetworzonego złomu różnych stopów miedzi. Dodatek ołowiu w stopie poprawia jego lejność i minimalizuje skurcz odlewniczy. Trudno jednak powiedzieć, czy w tym przypadku był dodatkiem intencjonalnym, czy też pochodzącym z wykorzystanego wtórnie surowca. Ślady srebra w obu próbach i złota w jednym przypadku mogą być pozostałością po jakiejś formie zdobienia powierzchni lub razem z żelazem, niklem i arsenem - stanowić pierwiastki śladowe pochodzące $\mathrm{z}$ rudy.

\section{STEMPEL PUBLIUSZA CIPIUSZA POLIBIUSZA}

Stempel na naczyniu z Grudnej nie został odbity dość dokładnie bądź zatarł się z czasem, co uniemożliwia jego precyzyjne odczytanie. Bez wątpienia rozpoznać można litery ...CIPIPOLIBI... oraz dodatkowo ostatnią literę, prawdopodobnie „F” 
Tabela 1. Zestawienie znanych stempli Publiusza Cipiusza Polibiusza z terenu Skandynawii, północnej Polski i północnych Niemiec (na podstawie: Imer 2007; Kunow 1985)

Table 1. Table of the stamps of Publius Cipius Polybius known from Scandinavia, northern Poland and northern Germany (after: Imer 2007; Kunow 1985)

\begin{tabular}{|c|c|c|c|c|c|c|c|}
\hline l.p. & Stanowisko & Kraj & $\begin{array}{c}\text { Typ } \\
\text { naczynia }\end{array}$ & Kontekst & $\begin{array}{c}\text { Data } \\
\text { odkrycia }\end{array}$ & $\begin{array}{c}\text { Chrono- } \\
\text { logia }\end{array}$ & Stempel \\
\hline 1 & Havor 1 & $\begin{array}{l}\text { Szwecja } \\
\text { (Gotlandia) }\end{array}$ & $\begin{array}{l}\text { brązowy rondel, } \\
\text { typ E } 142\end{array}$ & skarb & 1961 & B2 & (P CI) PI POLYB(I) \\
\hline 2 & Havor 3 & $\begin{array}{l}\text { Szwecja } \\
\text { (Gotlandia) }\end{array}$ & $\begin{array}{l}\text { brązowy rondel, } \\
\text { typ E } 142\end{array}$ & skarb & 1961 & $\mathrm{~B} 2$ & $\ldots$..IPI... \\
\hline 3 & $\begin{array}{l}\text { Kossin } \\
\text { (Kosin) }\end{array}$ & Polska & $\begin{array}{l}\text { brązowy rondel, } \\
\text { typ E } 142\end{array}$ & $\begin{array}{l}\text { znalezisko } \\
\text { grobowe }\end{array}$ & 1883 & $\mathrm{~B} 1 \mathrm{~b} / \mathrm{B} 2$ & PCIPIPOLIBY \\
\hline 4 & Stangerup & Dania & $\begin{array}{l}\text { brązowy rondel, } \\
\text { typ E } 142\end{array}$ & $\begin{array}{l}\text { inhumacja, znalezi- } \\
\text { sko grobowe }\end{array}$ & 1881 & B2 & $\begin{array}{l}\mathrm{P} \cdot \mathrm{CIPI} \cdot \mathrm{POLIBI}(\mathrm{F}) \\
\text { (Fecit?) }\end{array}$ \\
\hline 5 & Saustrup & Niemcy & $\begin{array}{l}\text { brązowy rondel, } \\
\text { typ E } 142\end{array}$ & $\begin{array}{l}\text { znalezisko } \\
\text { grobowe? }\end{array}$ & przed 1865 & $\mathrm{~B} 2$ & $(\ldots) \mathrm{IBY}$ \\
\hline 6 & Herskind & Dania & $\begin{array}{l}\text { brązowy rondel, } \\
\text { typ E } 143\end{array}$ & $\begin{array}{l}\text { znalezisko } \\
\text { grobowe }\end{array}$ & 1953 & B2 & (P)OLYB... \\
\hline 7 & $\begin{array}{l}\text { Sverkildstrup } \\
\text { Mark }\end{array}$ & Dania & $\begin{array}{l}\text { brązowy rondel, } \\
\text { typ E } 143\end{array}$ & - & 1877 & $\mathrm{~B} 2$ & $(\mathrm{P}) \cdot \mathrm{CIPI} \cdot \mathrm{POLI}(\mathrm{BI} \cdot \mathrm{F})$ \\
\hline 8 & Kalo & Dania & $\begin{array}{l}\text { brązowy rondel, } \\
\text { typ E } 142\end{array}$ & - & ok. 1855 & & $\ldots \mathrm{IPI}(\cdot) \mathrm{OLI} \ldots$ \\
\hline 9 & $\begin{array}{l}\text { Monbjerg } \\
\text { Mark }\end{array}$ & Dania & $\begin{array}{l}\text { brązowy rondel, } \\
\text { typ E142-143 }\end{array}$ & $\begin{array}{l}\text { inhumacja, znalezi- } \\
\text { sko grobowe }\end{array}$ & 1868 & $\mathrm{~B} 2$ & $\begin{array}{l}\text { P.CIPI } \cdot \text { POLIBI } \cdot \mathrm{F} \\
\text { (Fecit?) }\end{array}$ \\
\hline 10 & Skrřbeshave & Dania & $\begin{array}{l}\text { brązowy rondel, } \\
\text { typ E } 142\end{array}$ & $\begin{array}{l}\text { inhumacja, znalezi- } \\
\text { sko grobowe }\end{array}$ & 1933 & $\mathrm{~B} 2$ & ...POLIBI... \\
\hline 11 & Favrskov 1 & Dania & $\begin{array}{l}\text { brązowy rondel, } \\
\text { typ } 144 \text { (mały) }\end{array}$ & $\begin{array}{l}\text { inhumacja, znalezi- } \\
\text { sko grobowe }\end{array}$ & 1932 & $\mathrm{~B} 1 \mathrm{~b}$ & I.POLIB \\
\hline 12 & Favrskov 2 & Dania & $\begin{array}{l}\text { brązowy rondel, } \\
\text { typ } 146 \text { (mały) }\end{array}$ & $\begin{array}{l}\text { inhumacja, znalezi- } \\
\text { sko grobowe }\end{array}$ & 1932 & $\mathrm{~B} 1 \mathrm{~b}$ & PI·POLIB \\
\hline 13 & Favrskov 3 & Dania & $\begin{array}{l}\text { brązowy rondel, } \\
\text { typ } 144 \text { (mały) }\end{array}$ & $\begin{array}{l}\text { inhumacja, znalezi- } \\
\text { sko grobowe }\end{array}$ & 1932 & $\mathrm{~B} 1 \mathrm{~b}$ & $\ldots \mathrm{OL} \ldots$ \\
\hline 14 & $\begin{array}{l}\text { Annasholm } 1 \\
\text { „Marien- } \\
\text { lund” }\end{array}$ & Dania & $\begin{array}{l}\text { brązowy rondel, } \\
\text { typ E } 142 \text { (mały) }\end{array}$ & $\begin{array}{l}\text { inhumacja, znalezi- } \\
\text { sko grobowe }\end{array}$ & 1898 & B2 & (P)CIPIPOLYBI \\
\hline 15 & $\begin{array}{l}\text { Annasholm } 2 \\
\text { „Marien- } \\
\text { lund" }\end{array}$ & Dania & $\begin{array}{l}\text { brązowy rondel, } \\
\text { typ E } 142 \text { (mały) }\end{array}$ & $\begin{array}{l}\text { inhumacja, znalezi- } \\
\text { sko grobowe }\end{array}$ & 1898 & B2 & CIPIPOLYBI \\
\hline 16 & Grudna & Polska & $\begin{array}{l}\text { brązowy rondel, } \\
\text { typ E } 142\end{array}$ & znalezisko grobowe & 2012 & B2 & P.CIPIPOLIBIF \\
\hline 17 & Marwedel & Niemcy & $\begin{array}{l}\text { brązowy rondel, } \\
\text { typ E } 142\end{array}$ & znalezisko grobowe & 1964 & B2 & PCIPIBILIBII \\
\hline 18 & Sottorf & Niemcy & $\begin{array}{l}\text { brązowy rondel, } \\
\text { typ E } 142\end{array}$ & znalezisko grobowe & XIX/XX w. & B2 & P.CIPIPOLIBI \\
\hline 19 & Wilhelmshof & Niemcy & $\begin{array}{l}\text { brązowy rondel, } \\
\text { typ E } 142\end{array}$ & znalezisko grobowe & 1987 & B2 & \\
\hline
\end{tabular}




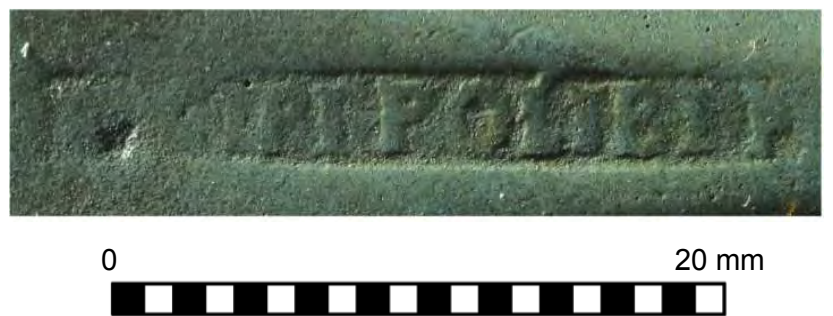

Ryc. 4. Grudna, stan. 2, pow. złotowski. Stempel Publiusza Cipiusza Polibiusza umieszczony na uchwycie naczynia (fot. M. Gembicki)

Fig. 4. Grudna, site 2, Złotów county. A stamp of Publius Cipius Polybius on a handle of the skillet (photo by M. Gembicki)

lub „P”. Bardzo nieczytelnie odbita została pierwsza litera, najprawdopodobniej „P”, za którą następuje znak kropki, jednak miejsce to jest zniekształcone przez drobny ubytek w masie naczynia (ryc. 4). Analizując różne znane warianty stempli Publiusza Cipiusza Polibiusza (Bennett, Young 1981; Imer 2007, s. 48-57; Kunow 1985, s. 223, 232-242), z największym prawdopodobieństwem należy stwierdzić, że na naczyniu z Grudnej znajduje się stempel w wersji „P.CIPIPOLIBI F”. W zapisie takim nomen na każdym stemplu odnosi się do rodziny lub firmy, natomiast cognomen dotyczy warsztatów lub aktualnych wykonawców (Bennett, Young 1981, s. 38), litera „F” natomiast oznacza prawdopodobnie fecit (ryc. 3). Zapis zbliżony do tego można zaobserwować na naczyniach ze Stangerup, Sverskildstru i Monbjerg Mark (tabela 1).

\section{WYROBY PUBLIUSZA CIPIUSZA POLIBIUSZA NA TERENIE CESARSTWA RZYMSKIEGO}

$\mathrm{Na}$ terenie Cesarstwa Rzymskiego odkryto wiele ostemplowanych rondli, które powstały w zakładach kapuańskich brązowników. Do najpowszechniejszych zaliczyć należy znaki rodzin „Cipi” i „Ansi”. Wytwórcy ci byli szczególnie aktywni w środkowych dekadach I w. n.e. Richard Petrovszky w obszernej pracy Studien zu römischen Bronzegefäßen mit Meisterstempeln wymienia 11 wytwórców z rodziny Cipi (Petrovszky 1993, s. 139-180). Badając zagadnienie chronologii i dystrybucji ostemplowanych naczyń rzymskich, J. Bennet i R. Young wymieniają znaleziska z warsztatów Ansiusa Diodoriusa i Ansiusa Epaphroditiusa, a także Cipiusa Isocrysusa, Cipiusa Augustalisa, Cipiusa Nicomachusa i Cipiusa Polybiusa (Bennet, Young 1981, s. 38). Naczynia oznaczone stemplem tego ostatniego stanowią znaleziska zdecydowanie najczęstsze (ryc. 5). Spośród rondli produkowanych w warsztatach rzymskich brązowników wyróżniono kilkanaście typów (Eggers 1951, s. 381-382, tab. 12-13). Stemple Publiusza Cipiusza Polibiusza spotykano na ron- 
dlach odpowiadających typom E 131, E 138, E 142, E 143, E144, E146, E 147 wg Eggersa (Eggers 1951, s. 381-382, tab. 12-13). Zdecydowana większość znanych stempli została odbita na naczyniach typu E 142 (Kunow 1985, s. 225), którego egzemplarz odkryto w Grudnej.

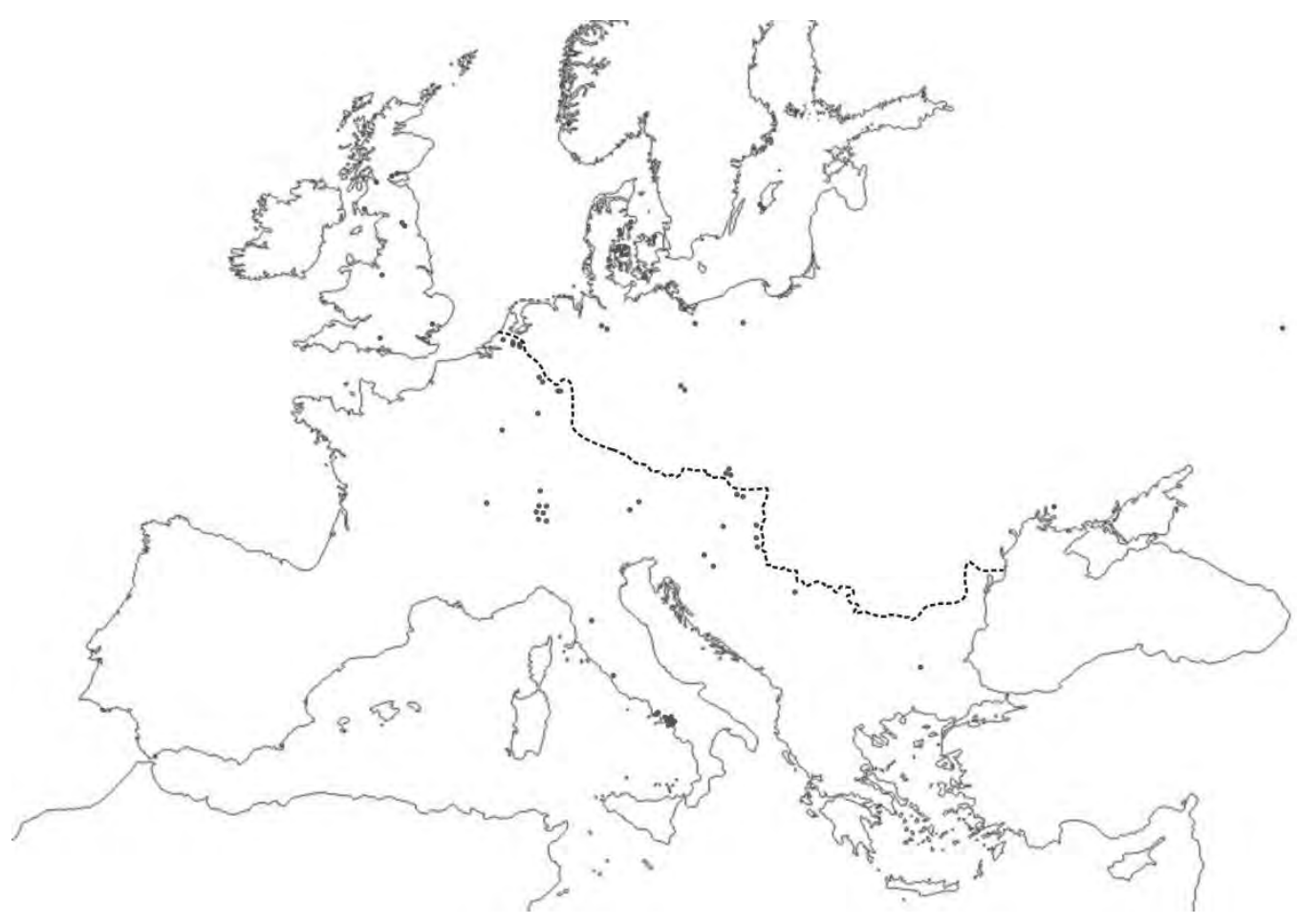

Ryc. 5. Znaleziska naczyń brązowych ze stemplem Publiusza Cipiusza Polibiusza z terenu Europy (na podstawie: Imer 2007; Kunow 1985; Petrovszky 1993)

Fig. 5. Bronze vessels with a stamp of Publius Cipius Polybius from Europe (after: Imer 2007; Kunow 1985; Petrovszky 1993)

\section{CHRONOLOGIA DZIALALNOŚCI PUBLIUSZA CIPIUSZA POLIBIUSZA}

Pierwsze próby określenia chronologii naczyń ze stemplem Polibiusza i wskazanie okresu, w którym jego wytwórnia była najbardziej aktywna, podjęto już na początku XX w. H. Willers w 1907 r. ulokował jego wytwórczość w latach 41-68 n.e. Następnie kilkakrotnie różni badacze przesuwali ten okres między rokiem 30 a 90 n.e. H.J. Eggers w 1966 r. określił chronologię naczyń Polibiusza na fazę $\mathrm{B}_{2}$, a w 1981 J. Bennet i R. Young analizując konteksty odkryć stemplowanych naczyń na terenie 
Wielkiej Brytanii, doszli do wniosku, że największa aktywność brązownika musiała przypadać na lata 65-85 n.e. (Bennet, Young 2013, s. 43). Z kolei J. Kunow dopatruje się początku produkcji jego naczyń w czasach Klaudiusza i Nerona, a koniec wiąże z nastaniem rządów Domicjana. Jednak największa aktywność warsztatu miała przypadać według niego na lata 60.-80. n.e. (Kunow 1985, s. 217, 220).

\section{BRĄZOWE RONDLE NA TERENIE CESARSTWA RZYMSKIEGO}

J. Bennet i R. Young zaliczają naczynie typu E 142 do rondli głębokich (Bennet, Young 2013, s. 37). W odróżnieniu od rondli płytkich występujących na terenie Cesarstwa, przeważnie w kontekstach łaźni rzymskich i określanych mianem bathsaucers (Bosanquet 1926, s. 107-111; Bennet, Young 2013, s. 37), rondle głębokie wiązane są zazwyczaj z różnymi kontekstami i często odkrywane są obok innych naczyń łączonych choćby ze spożyciem wina, jak w przypadku skarbu naczyń brązowych z Kingston Deverill ${ }^{2}$. Głębokie rondle w Cesarstwie Rzymskim pełniły zapewne różnorakie, dość uniwersalne funkcje. Na reliefie z Arlon widzimy na przykład rodzinę spożywającą posiłek. Głęboki rondel znajduje się na półce za nimi. Z kolei na kolumnie Trajana można dostrzec naczynia tego typu przytroczone do tobołków legionistów (Bennet, Young 2013, s. 38). Zresztą kontekst wojskowy w przypadku tych naczyń wydaje się odgrywać szczególną rolę, zwłaszcza na terenie Cesarstwa. Większość znalezisk naczyń tego typu odnotowano właśnie w pobliżu limesu, a na niektórych z nich można wręcz odczytać perforowane znaki sugerujące ich wojskową przynależność. Dodatkowym elementem widocznym na niektórych tylko naczyniach tego typu są linie ryte wewnątrz naczynia, pełniące funkcję zestandaryzowanej podziałki do odmierzania płynów bądź produktów sypkich. Część badaczy sugeruje, że każda grupa rzymskich legionistów posiadała rondel z podziałką, którego używała podczas racjonowania zapasów (Wright 1969, s. 1-5).

Znanych jest też kilka bardziej zdobionych, posrebrzanych rondli, jak np. egzemplarz z Capheaton, które mogły pełnić funkcje religijne i raczej nie były w codziennym użytku (Bennet, Young 2013, s. 38).

\section{BRĄZOWE RONDLE NA TERENIE BARBARICUM}

Z kolei naczynia stemplowane znakiem firmowym Polibiusza na terenach Barbaricum (ryc. 5), szczególnie zaś południowej Skandynawii, północnej Polski

\footnotetext{
${ }^{2}$ W lutym 2005 r. detektorysta przeszukujący zaorane pole w granicach parafii Kingston Deverill Wiltshire odkrył brązowe naczynie. Po zawiadomieniu odpowiednich służb przeprowadzono w miejscu odkrycia prace wykopaliskowe. W trakcie prac natrafiono na depozyt brązowych naczyń: 2 rondle, z których jeden (typu E142) oznaczony był stemplem Publiusza Cipiusza Polibiusza, oraz dwie misy z sitami do odcedzania wina (http://www.wshc.eu/vessel-hoard.html).
} 
i Niemiec (ryc. 5), niemal zawsze występują w kontekstach grobowych (tabela 1). Wyjątek od tej reguły stanowią dwa naczynia ze stanowiska Havor 1 i 3 na Gotlandii, które odkryto w kontekście skarbów. Pozostałych 17 znanych naczyń zdeponowano w grobach. Niestety znaczna część z nich to znaleziska jeszcze z XIX bądź $\mathrm{z}$ początku XX w., często przypadkowe lub niedostatecznie udokumentowane, co jest typowe dla wczesnych etapów rozwoju archeologii.

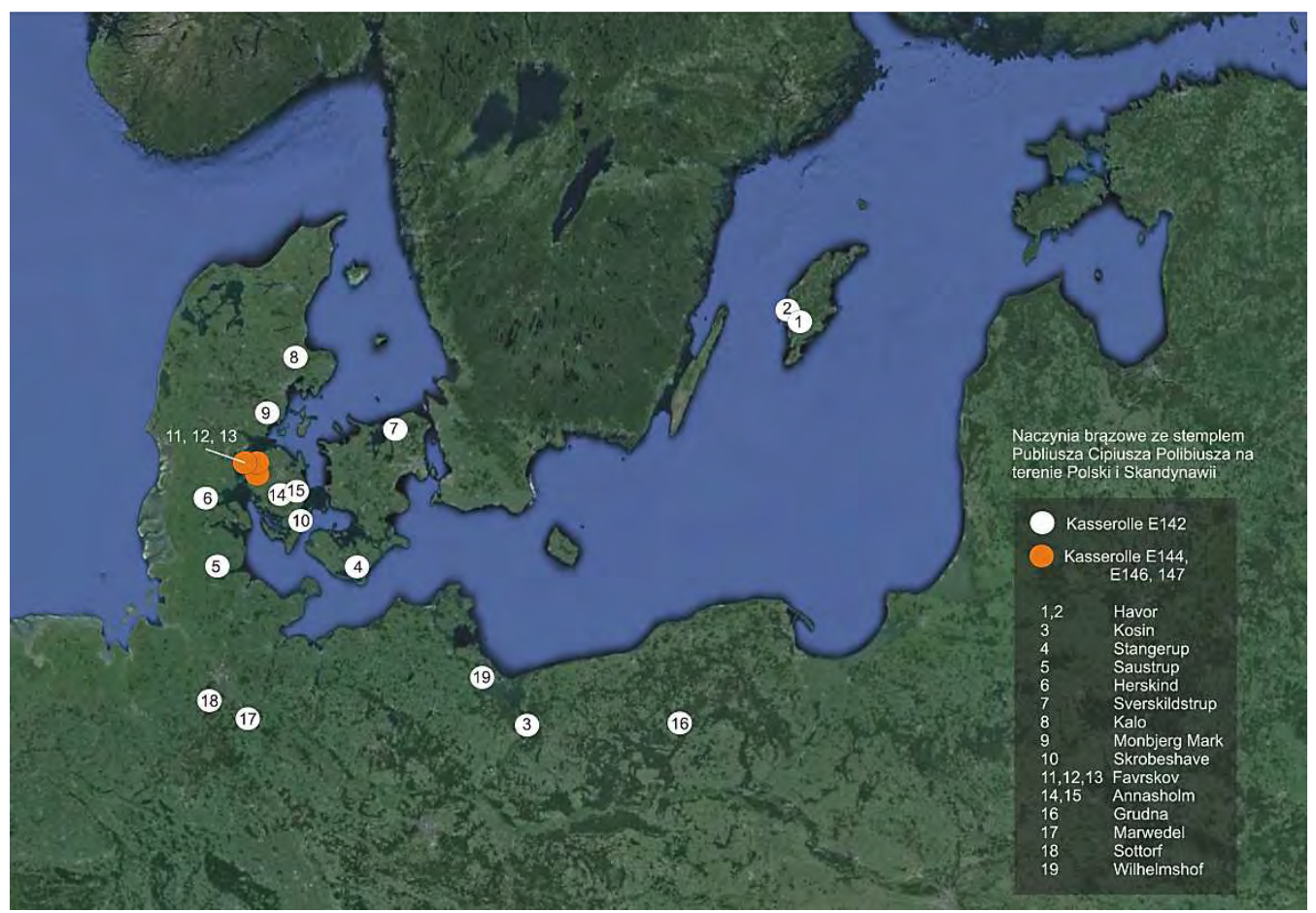

Ryc. 6. Znaleziska naczyń brązowych ze stemplem Publiusza Cipiusza Polibiusza z obszaru Morza Bałtyckiego (na podstawie: Imer 2007; Kunow 1985; Petrovszky 1993)

Fig. 6. Bronze vessels with a stamp of Publius Cipius Polybius from the Baltic Sea region (after: Imer 2007; Kunow 1985; Petrovszky 1993)

Pierwsze naczynie Polibiusza z terenów Polski odkryto w 1883 r. na Pomorzu Zachodnim, w miejscowości Kosin (Kossin) w gminie Przelewice, pow. pyrzycki. Natrafiono tam na grób szkieletowy nakryty brukiem kamiennym. W jego wnętrzu znajdowały się, wg różnych źródeł, 2 naczynia szklane, brązowy rondel odpowiadający typowi E142-143 ze stemplem PCIPIPOLIB (ryc. 7) oraz fragmenty jeszcze innego, bliżej nieokreślonego naczynia brązowego (Eggers i Stary 2001, s. 94, tab. 269). Nie jest znany dokładny opis konstrukcji grobu, jednak z pobieżnych danych 
wynika, że obiekt ten można łączyć z grupą pochówków typu „Lubieszewo”, interpretowanych na terenie Barbaricum jako groby lokalnej elity (Wołągiewicz 1997; Schuster 2010, s. 328, tam dalsza bibliografia). Umieszczenie naczyń brązowych w grobie można wiązać ze sposobem zaznaczania wysokiego statusu społecznego zmarłego. Oczywiście mało prawdopodobne jest, by w tej sytuacji obecność stempla czyniła je dla żyjących ówcześnie ludzi bardziej wartościowym od podobnych, lecz nieoznaczonych.

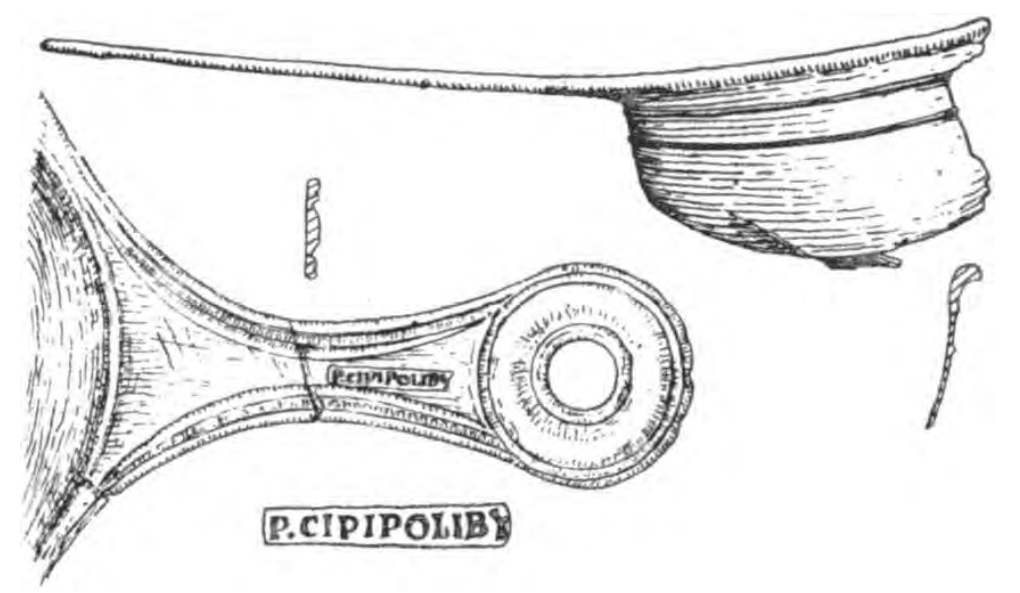

Ryc. 7. Naczynie brązowe ze stemplem Publiusza Cipiusza Polibiusza znalezione w Kosinie, woj. zachodniopomorskie (na podstawie: Eggers, Stary 2001)

Fig. 7. A bronze vessel with a stamp of Publius Cipius Polybius from Kosin, Western Pomerania (after: Eggers, Stary 2001)

Znaleziska naczyń brązowych importowanych na tereny południowego wybrzeża Bałtyku u schyłku I w. do połowy II w. (faza $\mathrm{B}_{2}$ ) wiązane są przez R. Wołągiewicza $\mathrm{z}$ funkcjonowaniem dwóch głównych szlaków handlowych. Pierwszy z nich miał biec z kierunku południowego wzdłuż tzw. szlaku bursztynowego. Drugi, bardziej istotny z perspektywy dystrybucji naczyń brązowych, wiódł „,północnym szlakiem morskim". Jego istotnym punktem był węzeł tranzytowy na półwyspie Jutlandzkim i wyspach duńskich (Wołągiewicz 1970, s. 232-233). Rozmieszczenie naczyń wykonanych przez warsztat Polibiusza wskazuje na ich silną koncentrację właśnie w tych rejonach (ryc. 6). Intensywność obustronnej wymiany handlowej i kulturowej, która odbywała się dzięki funkcjonowaniu północnego szlaku morskiego, spowodowała wg H. Machajewskiego dynamiczny rozwój kontaktów kulturowych w tej strefie Bałtyku. Wymiana ta stała się impulsem do wzmożonego rozwoju wielu rodzajów zajęć rękodzielniczych, m.in. odlewnictwa i jubilerstwa. Dlatego na południowym wybrzeżu Bałtyku pojawiło się wiele wytworów metalowych osadzonych $\mathrm{w}$ tradycji skandynawskiej, nadłabskiej i kultury wielbarskiej 
(Schuster 2005, s. 101-113, Machajewski 2012, s. 210). Rozwój osadnictwa na bazie różnych od siebie tradycji kulturowych $\mathrm{w}$ fazie $\mathrm{B}_{2}$ spowodował powstanie na Pomorzu Zachodnim skupień osadniczych o wyjątkowym charakterze (Machajewski 2011, s. 425, ryc. 12). Główne z nich można zidentyfikować w dorzeczu dolnej Regi, w rejonie pyrzyckim, na Pojezierzu Myśliborskim oraz w dorzeczu górnej Regi i Drawy. Szczególne znaczenie przypisywane jest skupieniu z dorzecza dolnej Regi, które miało pełnić już $\mathrm{w}$ fazie $\mathrm{B}_{1}$ funkcję ważnej strefy kontaktowej dla różnych nurtów kulturowo-osadniczych południowego pobrzeża Bałtyku (Machajewski 2012, s. 211). Rozwój osadnictwa kultury wielbarskiej miał z kolei pobudzić w fazie $\mathrm{B}_{2}$ powstawanie nowych skupień w dorzeczu górnej Regi i Drawy.

Analizując historię odkryć archeologicznych powiatu złotowskiego (Götze 1904, s. 3-5; Karpińska 1926, s. 22-23; Kokowski 1997b, s. 9-55, 1988, s. 15-16) chociażby cmentarzysk kurhanowych w Debrznie, Dorotowie i Zelgniewie oraz znaleziska z pobliskiego Lędyczka (Biborski, Kaczanowski 2001, s. 69-78), można dojść do wniosku, że podobną rolę musiało odgrywać także skupisko osadnicze z pogranicza wielkopolsko-pomorskiego w dorzeczu środkowej Gwdy.

\section{CHRONOLOGIA GROBU Z GRUDNEJ}

Kwestia daty produkcji rondla z Grudnej jest ściśle powiązana z opisaną powyżej dyskusją na temat chronologii twórczości Polibiusza. Natomiast osobnym zagadnienieniem jest funkcjonowanie importów w społecznościach barbarzyńskich oraz chronologia grobu, w którym je zdeponowano. Należy wziąć pod uwagę kontekst odkrycia oraz współwystępowanie innych podobnych znalezisk na terenie Barbaricum (tabela 1). Można zauważyć, że naczynia tego typu na interesującym nas terenie przeważnie datowane są na fazę $\mathrm{B}_{2}$ okresu wpływów rzymskich, rzadziej na fazę $\mathrm{B} 1_{\mathrm{b}}$ (tabela 1). Naczynie z Kosina wiązanego z grobami stylu „Lubieszewo” (Wołągiewicz 1997; Schuster 2010, s. 328, tam dalsza bibliografia) datuje się na przełom fazy $B_{1 b}$ i $B_{2}$ (Eggers, Stary 2001, s. 94). Współwystępowanie w zespole grobowym z Grudnej takich zabytków, jak duży szklany paciorek, fragment kościanego grzebienia i szpili kościanej pozwalają datować obiekt na fazę $B_{2}$. Pojawienie się szpil kościanych w kulturze wielbarskiej obserwuje się $w$ fazie $B_{2 b}$, najliczniej jednak występują one w zespołach z fazy $\mathrm{B}_{2} / \mathrm{C}_{1}$, rzadziej zaś w okresie późnorzymskim (Tempelmann-Mączyńska 1989, s. 65-77). Podobnie datuje się okucia żelazne i brązowe skrzynek oraz zamków, których pozostałości także odkryto w Grudnej (Kokowski 1997b, s. 37-39). Pozwala to doprecyzować chronologię znaleziska. Uwzględniając powyższe informacje, można stwierdzić, że rondel ze stemplem Polibiusza wyprodukowany prawdopodobnie w latach $60-80$ n.e. w pobliżu Capui został zdeponowany w grobie w Grudnej w podfazie $B_{2 b}$ okresu wpływów rzymskich, a więc w latach $110 / 120-160$ n.e. 
Wstępne wyniki badań archeologicznych na cmentarzysku kurhanowym w Grudnej wskazują na silne powiązania lokalnej społeczności z tradycjami wielbarskimi i skandynawskimi zarówno w zakresie kultury materialnej, jak i sposobów chowania zmarłych. Analizowane naczynie ze stemplem Publiusza Cipiusza Polibiusza ze stanowiska nr 2 w Grudnej jest tutaj tylko jednym z przykładów rozbudowanych, ponadregionalnych kontaktów ludności zamieszkującej rejony dorzecza środkowej Gwdy w okresie wpływów rzymskich.

\section{BIBLIOGRAFIA}

Bennett J., Young R.

1981 Some New and Some Forgotten Stamped Skillets, and the Date of P. Cipius Polybius. Britannia, 12, s. 37-44.

Biborski M., Kaczanowski P.

2001 Neue römische importe aus dem Gebiet Polens. Pyxidi aus Lędyczek, Kr. Piła. W: J. Kolendo, A. Bursche (red.), Nowe znaleziska importów rzymskich z ziem Polski. Korpus znalezisk rzymskich z europejskiego Barbaricum. Polska (t. 2, s. 69-78). Warszawa: Instytut Archeologii Uniwersytetu Warszawskiego.

Bosanquet R.

1926 A Stamped Bronze Handle, W: R.E.M. Wheeler, The Roman Fort near Brecon. London: Cymmrodorion Society.

Eggers H.J.

1951 Der römische Import im freien Germanien. Atlas der Urgesichte (band 1). Hamburg: Hamburgisches Museum für Völkerkunde und Vorgeschichte.

Eggers H.J., Stary P. F.

2001 Funde der vorrömischen Eisenzeit, der römischen Kaiserzeit und der Völkerwanderungszeit in Pommern. Lübstorf: Archäologisches Landesmuseum für Mecklenburg-Vorpommern.

Götze A.

1904 Hügelgraber der römischen Zeit von Selgesnau, Kreis kolmar in Posen. Nachrichten über deutsche Altertumsfunde, 1, s. 3-5.

Imer L.M.

2007 Greek and Latin inscriptions in the northern Barbaricum. W: T. Grane (red.), Beyond the roman frontier. Roman Influences on the Norther Barbaricum (s. 31-60). Roma: Quasar.

Karpińska A.

1926 Kurhany z okresu rzymskiego w Polsce ze szczególnem uwzględnieniem typu siedlemińskiego. [Maszynopis pracy licencjackiej, Instytut Prahistorii UAM, Poznań].

Kokowski A.

1988 Problematyka kultury wielbarskiej w młodszym okresie rzymskim. W: J. Gurba (red.), Kultura wielbarska w mtodszym okresie rzymskim (s. 15-33). Lublin: Uniwersytet Marii Curie-Skłodowskiej.

Kokowski A.

1997a Schlossbeschlage und Schlussel im Barbaricum in der Romischen Kaiserzeit und der Fruhen Volkerwanderungszeit. Klassifizierung. Verbreitung. Chronologie. Lublin: Uniwersytet Marii Curie-Skłodowskiej. 
Kokowski A.

1997b Dzieje zainteresowań starożytnościami na terenie byłego powiatu złotowskiego. W: H. Piszczek (red.), Złotów: na pograniczu dwóch kultur. Materiaty z sesji popularnonaukowej z okazji 35-lecia działalności Muzeum Ziemi Złotowskiej (s. 9-56, 89-100). Nakło-Złotów: Wydawnictwo Pagina, Muzeum Ziemi Złotowskiej.

Kunow J.

1985 Die Kapuanishen Bronzegefassersteller Luciu Ansius Epaphroditus und Publius Cipius Polybius. Bonner Jahrbücher, 185, s. 215-242.

Machajewski H.

2011 Ze studiów nad formami osad z okresu rzymskiego w dorzeczu dolnej Odry. Przykład osady z Czarnowa, pow. pyrzycki, woj. zachodniopomorskie. W: A. Jaszewska (red.), Z najdawniejszych dziejów. Grzegorzowi Domańskiemu na pięćdziesięciolecie pracy naMachajewski $\mathrm{H}$ ukowej. Zielona Góra: Wydawnictwo Fundacji Archeologicznej.

2012 Wprowadzenie do problematyki kulturowej zabytków z okresu wpływów rzymskich I wczesnej fazy okresu wędrówek ludów (V/VI wiek). W: K. Kowalski, D. Kozłowska-Skoczka, Zaginione - ocalone: szczecińska kolekcja starożytności pomorskich. Szczecin: Muzeum Narodowe.

Petrovszky R.

1993 Studien zu römischen Bronzegefäßen mit Meisterstempeln (Kölner Studien zur Archäologie der römischen Provinzen 1). Buch am Erlbach: VML Verlag Marie Leidorf GmbH.

Tempelmann-Mączyńska M.

1989 Das Frauentrachtzubehör des mittel- und ost-europäischen Barbaricums in der römischen Kaiserzeit. Kraków: Uniwersytet Jagielloński.

Willers H.

1907 Neue Untersuchlungen über die römische Bronzeindustrie von Capua und Niedergermanien. Besonders auf die Funde aus Deutschland und dem Norden hin. Hannover/Leipzig: Hahnsche Buchhandlung.

Schuster J.

2005 Die Beziehungen der Gebiete Ostbrandenburgs im späten zweiten und frühen dritten Jahrhundert zur Wielbark- und Przeworsk-Kultur. Miteiner formen kundlichen Untersuchung der Fibeln A II, 41. Veröffentlichungenzur Brandenburgischen Landesarchäologie, 36/37, 2002/2003(2005), s. 89-161.

Schuster J.

2010 Lübsow. Älterkaiserzeitliche Fürstengräber im nördlichen Mitteleuropa. Bonner Beiträgezur Vor- und Frühgeschichtlichen Archäologie, 12.

Wołągiewicz R.

1970 Napływ importów rzymskich do Europy na północ od Dunaju. Archeologia Polski, 15, s. $207-242$.

Wołągiewicz R.

1997 Lubieszewo. Materiaty do studiów nad kultura spoleczności Pomorza Zachodniego w okresie od IV w. p.n.e. do I w. n.e. Szczecin: Muzeum Narodowe.

Wright R.P.

1969 Two bronze vessels from Northumberland and new readings of the names of other makers. W: J. Philipson (red.), Archaeologia Aeliana or Miscellaneous Tracts Relating to Antiquity (4th Series, vol. XLVII, s. 1-5). Newcastle-upon-Tyne: Society of Antiquaries of Newcastle upon Tyne. 


\title{
IMPORTED BRONZE SKILLET WITH A STAMP \\ OF PUBLIUS CIPIUS POLYBIUS FROM THE ROMAN IRON AGE BARROW CEMETERY AT GRUDNA, SITE 2, ZŁOTÓW COUNTY
}

\begin{abstract}
Su m mary
During excavations at the Roman Iron Age barrow cemetery in Grudna there has been an imported vessel discovered with a stamp of Publius Cipius Polybius, a bronzesmith of Capua. It was found in an inhumation burial with a stone setting. Numerous discoveries of products by Polybius from the territory of Roman Empire and Barbaricum permit an assumption that at the time he was the most prolific bronzesmith known by his name. The skillet discovered in Grudna, according to the typology of Roman imports by H. J. Eggers, represents type E142. A detailed analysis of the manufacturer's stamp reveals an inscription (P.)CIPIPOLIBI(.F). In the Roman Empire, such vessels have been discovered in various contexts, although most often in military one. They are particularly common in the frontier areas, the Limes. Within Barbaricum, skillets have been found almost exclusively in burial context in graves dating from phase $\mathrm{B}_{1 \mathrm{~b}} / \mathrm{B}_{2}$ of the Roman Iron Age. A concentration of such wares has been observed on Danish islands. The presence of imported skillet at Grudna, along with an analysis of changes in the settlement system and social structure within the south Baltic area, suggest widespread interregional contacts of communities inhabiting the middle Gwda River basin in phase $\mathrm{B}_{2}$ of the Roman Iron Age.
\end{abstract}

Translated by Lucyna Leśniak 